\title{
Heidegger and Hegel on Being: A Comparative Analysis
}

\author{
Peter Z. Alawa \\ University of Port Harcourt Department of Philosophy
}

\begin{abstract}
Martin Heidegger is a German philosopher. He is called "the philosopher of Being". For Heidegger, Being is a mystery. Friedrich Hegel is also a German philosopher, he believes in being and the Absolute spirit. According to Hegel the Absolute Spirit is not Holy Spirit or God but the principle that guides the universe. Heidegger and Hegel believe in the existence and reality of being. The difference is that Heidegger maintains that "Being" is a mystery that can be approached but cannot be penetrated. While Hegel believes that human reason can encompass or penetrate all realities. Our method is textual analysis. It means reflecting on the original works of our authors and also books written on them by other writers to discover the similarities and differences between Hegel and Heidegger.
\end{abstract}

Accepted Date: 29 June 2013

\section{Introduction}

The question "what is the meaning of being"? historically speaking is not an easy task. The term "being" disturbed the minds of philosophers from ancient to contemporary periods. Parmenides of Elea was the first who articulated the idea of being by saying being "is" and non-being "is not". For Hediegger, all other philosophers had forgotten Being. But Hegel tried to resolve the problem of being by saying in being there is non-being. In this work, we are looking at what is being, Heidegger on Being, Hegel on being, similarities and differences between Hegel and Heidegger, evaluation and conclusion. However, instead of much argument let us start with being.

\section{What Is Being?}

Even though being cannot be defined, it has origin. The term "being" etymologically means in Latin = ens, Greek $=$ on French $=$ Etant, in German $=$ Sein which connotes existing. Being is that which exists or at least is capable of existing.

According to Aristotle being is here and concrete in this world, we can see it and it can transcend itself. For Aristotle, whatever "is" is a being, being can be a goat, a house, a man, a stone, an angel. Aristotle's metaphysics cannot treat "Being", this is because "Being" is not an entity of any sort. Here Heidegger goes beyond Aristotle.

For Plotinus, being is the "One" and after the "One" there is nothingness. Rex Warner commenting Plotinus writes:

The One is all things, and yet no one of all. For the principle of all is not all things, but the one is all, because all things run as it were into it or rather do not yet exist, but will be. ${ }^{1}$

Understanding Plotinus the One is simple, and in it there is no variation. Hence, in order that being must exist, the One is not being but Being is the progeny of it, and as it were its first form. Being is the same manner as the One produces things similar to itself through an effusion of abundant power.

St. Thomas Aquinas follows Aristotle in identifying being as being but maintains that "God is being par excellence while creatures are being in analogical sense".

John Scotus on his part, accepted being as what is, but contrary to Aquinas, Scotus says being can be described both to God and creatures. Therefore, being is univocal for Scotus and not analogical.

Kant sees being as a general concept that is not the same as particular being. For Kant being is an ontological characteristic that belongs to every being, actual and possible. Kant remarks:

Being is evidently not a real predicate or a concept that can be added to the concept of thing. It is merely an admission of a thing and of certain determinations in it. Logically, it is merely the copular of judgment. ${ }^{3}$

Kant maintains that there is created being (ens creata) and uncreated being (ens increate).

Jean-Paul Sartre identifies being with whatever "is". He refuses to take any mystical approach to the issue of being. Being for Sartre is not a hidden reality in which objects participate. It is incorrect, says Sartre, to say that objects possess being or that they participate in being. Whatever "is" is a being. For Sartre, there are two kinds of being, namely; being-in-for-itself (Pour-Soi) and being-in-itself (en-Soi). The former is conscious being while the latter is unconscious. Sartre says: 
The object does not possess being and its existence is not a participation in being, nor other kind of relation. It is. That is the only way to define its manner of being. ${ }^{4}$

According to Sartre, objects are being themselves and they do not need intermediary or relation to become being. Sartre believes that there is no necessity for the existence of being; necessity concerns the connection between ideal propositions but not that of existence. An existing phenomenon can never be derived from another existent qua existence.

Gabriel Marcel takes a mystical approach to the issue of being. He sees being as a mystery; a mystery in which our very existence is involved. Our encounter with "being" is by means of participation. Marcel also believes that we could relate to other beings when he says:

The more we affirm the being of others in the inter-subjectivity level, the more we are, but the less we affirm it, we also decrease the affirmation of our existence. ${ }^{5}$

Marcel's fundamental premise is that we can relate to others as a condition for our existence.

Strawson's own contribution about the study of being is remarkably similar to many things we now want to interpret Aristotle, which is based on substance. Commenting Strawson I. Fred writes:

Strawson's analysis is remarkably similar to Aristotle, Strawson affirms the priority of substance - property distinction; which Ayer attacked as a mistake of language. Like Aristotle, Strawson asserts that there is a base where all other things anchored on which does not change - that is substance. The main difference between Aristotle and Strawson is that for Aristotle, matter is the principle of individuation while for Strawson the individuating factor is the system of space and time. ${ }^{6}$

In summary, the ancient philosophers were interested in finding out what is it that makes things exist; Parmenides of Elea is recognized as the first person who articulated the meaning of being distinctively. The medieval philosophers see God as the fundamental of all things. The modern philosophers were pre occupied with the problem of substance rather than the problem of being. The contemporary philosophers see being as whatever is, others take it as a mystical reality, which is both immanent and transcdent; and which is the source of all things. Also some see being as we can relate to other people by the way of inter-subjectivity.

\section{Martin Heidegger On Being}

Heidegger shows us that there is a meaningful conception of Being, a conception that underlines all our understanding of reality. This does not mean, of course, that he was looking forever for the answer to the same old question. As his thinking evolved, his initial ideas on the question changed. For Heidegger Being (Sein) is different Seindes (beings). According to Martin Heidegger in his book An Introduction to Metaphysics says:

... Sein (Being). This substantive goes back to the infinitive "Sein" (to be) which belongs with the forms you are, he is, we were, they have been. "Being" as a substantive came out of the verb, the word "being" is a verbal substantative". 7

What Heidegger is saying here is that being is the participle of the verb "to be" and the verb "to be" means to exist, to have existence. Taken as a noun in the substantive form, it is equivalent to that which exists.

Why is Heidegger interested in Being. For him the problem of philosophy is not theory of knowledge but ontology and true enough is the meaning of Being. For Heidegger, knowledge is just one of the relationships we have with objects in this world. It is not the first in the hierarchy of relationships with objects because an object has independent existence irrespective of any lack of knowledge of its existence. Even when we know, such knowledge is often lazy and blurred and we never really have comprehensive and final knowledge of anything.

However, Heidegger's concept of Being is different from others. His whole philosophical career is in pursuit of Being and not beings. M. F. Asiegbu supporting Heidegger on Being says:

Heidegger's Being is not the "One" of Plotinus, the God and infinite Being of scholastic philosophers, not the Absolute spirit of Hegel, the transcendental phenomenology of Husserl, the omega point of Teilhard de Chardin, the material dialectic of Marx, The 'Being" of Heidegger is the hidden reality which evolves itself in every culture in place and time. ${ }^{8}$

Given the notion of time, not as locus or condition of existence, but as it is intrinsic ontological structure, we can now attempt to understand what Heidegger's Being means. Heidegger was asked what is Being? He explicitly said: "It is itself, future thought must learn to experience and express this. "Being" is neither God nor the basis of the world. Being is further from all that is being and yet closer to man than every being, be it rock, an animal, a work of art, a machine, be it an angel or God". ${ }^{9}$ Being is not a being or an entity, the problem of the meaning of Being remained the most fundamental question of philosophy. For Heidegger Being is an event and not substance. Heidegger believes Being conceals and also unconceals. Heidegger says in his book Discourse on Thinking thus: "That which shows itself and at the same time withdraws is the essential trait of what we call the mystery". ${ }^{10}$ 
As we indicated before that Heidegger approaches the problem of Being in three stages. The first stage Heidegger discussed the basic constitutive states of human being. Here we call the Dasein analysis - here human being reflects on his own existence and transcends itself to think of Being. Human beings are complex and they are also mysteriously. Dasein and Being are closely related. But Heidegger discovers that Being is still elusive, so he moved the second stage and dwells on art and truth as a path to Being.

Here Heidegger reflects on art and truth as a path to being and in this second stage Being takes precedence over Dasein. For Heidegger, art is not aesthetics; art is the disclosure of Being. Hediegger believes that truth is not correspondence but a-letheia. A-letheia means the essence of truth; that is, truth in its totality but not a particular truth. Heidegger also conclused that the real man of art and the man of technology, the thinker and the poet are all responding to the challenge of the call of Being.

In this final stage, Hediegger made a clear distinction between Being and beings and he calls it Ontolgoical Differnece. Heidegger attempts to discuss Being not as a substance but a process-gradual process of development and disclosure. In this stage we are discussing the ontological difference, Being as ousia and Being as a process.

The ontological difference is the stage where Dasein transcends other beings in the world and also itself to think of Being and Being takes precedence over Dasein. C. S. Nwodo commenting Heidegger on ontological difference says: "The fundamental issue within the phase of Being is the ontological Difference, the fact that Being is different from beings. ... if one fails to distinguish Being from beings, then for him Being is just another being. This leads to what Heidegger calls subjectivism of modern metaphysics, which treats Beign as being an object before a subject". ${ }^{11}$

However, we are to discuss Being as Ousia. Being as ousia goes back to the Greek sense of being. The Greeks believed that being is static, necessary, unchanging and eternal. Aristotle influenced Heideger on Being as ousia because being is permanent but Heidegger will go beyond Aristotle to Being as a process that is expressed as Ereignis and Gelassenheit.

Being as Ereignis: In discussing Being as Ereignis is our primary route to come to terms with the knowledge that Being for Heidegger is a mystery. A mystery is what is beyond explanation ordinarily through human reasoning. This stage for Heidegger is the period of meditation, at this stage Heidegger drops the word philosophy, he also drops his method phenomenological hermeneutics and uses the method called Thinking and Being. For Heidegger, Being uses man and it is only in silent meditation that human beings could approach the mystery of Being. Being is the opposite of all abstraction fashioned by human thought; it is what is given to thinking to think. Heidegger says: "this mutual belonging together of man and Being is Ereignis"12 In continuation Heidegger writes: "The event of appropriation is the realm in which man and Being reach each other in their very core" ${ }^{13}$ It is within this period Heidegger talks about two types of thinking. Calculative thinking and meditative thinking. Calculative thinking is characterized by human methods of approaching things; it deals with things in -terms of advantage. The second one is the thinking that is not used to tame nature and that is meditative thinking. Meditative thinking can also be called resignation and replacement (Gelassenheit) which Heidegger calls a "leap" and a "spring". It invites one to surrender to Being.

Reflecting on Gelassenheit Versenyi writes:

In its original use, by the German mystics, Gelassenhiet denoted the attitude and the state of mind who had resigned his own will, taken leave of himself and the world, and, relinquishing all that is earthly had devoted, entrusted and abandoned himself totally to God. The word had the connotation of a double movement: away from oneself and the world and to God. Inspite of Heidegger's reluctance to speak of God - "we come too late for the gods and too early for Being (ED7) - his use of the word carries the same overtones and refers to a relationship structurally the same as mystic Gelassenhiet. ${ }^{14}$

The word Gelassenheit is used by the German mystics. It means detachment from the world and oneself to devote, trust and abandon oneself to God. Heidegger got this idea from the mystics even though he did not mention God. But the word Gelassenhet had the connotation of a double movement which means withdrawing from earthly activities and oneself and resigning to Being.

At this stage, Being is no longer a permanent thing or ground of all things but a mystery in which one can only resign or one wait prayerfully to enable Being speak to you.

How will Being speak to you? At this level man does not know Being unless it reveals itself through poetic language. For Heidegger, the origin of language is mysterious, and it is through language people speak Being. According to Heidegger, the highest form of language is to be speechless - that is to be silent. Finally, Being for Heidegger is a mystery.

\section{Georg-W. Friedrich Hegel On Being}

G.W.F. Hegel was trying to resolve the problem Kant did in epistemology between empiricists and rationalists. In metaphysics, Hegel's science of logic is a vast treatise on the nature, origin, extent and forms of conceptual thought. Hegel describes the formation of concept as a process in which being emerges as essence. 
In the first volume of his book called the science of logic Hegel introduced his own being. For Hegel, being may be determined in three ways: (a) as determinateness of quality (b) as quantity (c) as measure. Hegel says pure being is not the same as pure nothing. Being and nothing may be moments of the process of becoming. Becoming may be vanishing of Being into nothing or of nothing into being. Hegel argues that determinate being through a process of ceasing to be. Determinate being is reality, while indeterminate being is an empty abstraction.

Hegel argues that being of things-in-themselves, in so far as it is assumed to be void of all being-forothers is an empty abstraction. The being of things in themselves cannot be known in so far as it is empty of any being for-other. The Being of things-in-themselves is actually being of their concepts or notions. Being for itself transcends otherness and it is called Absolute Being. This Absolute being is not God or personality it is the principle that governs the world.

Hegel by postulating a spiritual principle or substance he calls idea-in-itself, dynamic and self-creative. When it externalizes itself in space it is called nature. When nature evolves to the level of consciousness, it is called Spirit. This constitutes the Hegelian triad of idea, nature and spirit, which evolves dialectically as thesis, anti-thesis and synthesis. The synthesis forms a new thesis for development. The evolution of spirit in time, Hegel calls history; and this history he defines as the "autobiography of God". History is the process of divine self-liberation towards absolute freedom, which Hegel believes it takes different stages of realization in this world. Hegel confirms this in his work Philosophy of History when he says:

The time must eventually come for understanding that rich product of active reason, which history of the world offers us. It was for a while the fashion to proffers admiration for the wisdom of God is display in nature... Divine wisdom is one and the same in the great as in little, and we must not imagine God to be too weak to exercise his wisdom on the general scele. ${ }^{14}$

With Hegel, God manifests Himself in history. Hegel talks about being, non-being and becoming.

The question I may ask is, is there anyway one can use "nothing" as a positive answer? Yes! For example, your mother asks you, did you see any cup at the door as you were coming in. If you did not see it one will say mama nothing. This is positive answer. In more practical sense we do not articulate what is not being; we can have knowledge of science, investigating being.

'Non being' is the opposite of being. Parmenides says "non being" is a condition of nothingness and nothingness can produce nothing. The above statement of Parmenides created problem in the history of philosophy. But Hegel in another perspective believes in being there is non-being.

It means category of subjectivity is deduced from objectivity and in objectivity there is subjectivity.

\section{Similarities And Differences Between Heidegger And Hegel}

\section{Similarities}

For Heidegger and Hegel they believe in the existence and reality of being.

They also accepted that Being is not static but dynamic.

They believe that being is not God

They also accept nothingness not like Parmenides.

\section{Differences}

Martin Heidegger believes that Dasein, time and Being are spacio-temporal. It means Being exists in time. Heidegger accepted Being to be mystery. For him, Being is a mystery that can be approached but one cannot penetrate. While for Hegel, human reasoning can penetrate any reality.

Martin Heidegger believes that Being is not a noun but a verb and it is not a thing of any sort.

Hegel believes in absolute spirit and that other finite creatures participate in.

Hegel -attempts to give solution to the problem of being by saying in being there is non-being.

Heidegger did not mention anything about the problem of being, he only says "Being" conceals and unconceals.

\section{Evaluation}

On an evaluating note, one must give credit to Heidegger and Hegel for bringing back the question of the meaning of being. Heidegger must be respected for the bold step he took to discuss "Being" without prejudice of any religion purely on philosophical ground. He believes that "Being" is a mystery and he seems to allow Being in a continuous mystery. Heidegger says other philosophers had abandoned Being and now they are in pursuit of beings. According to Heidegger, Being is a mystery that one can only approach but cannot penetrate. Being is temporal because it is tied to time. We also give credence to Hegel because he attempted to resolve the old perennial problem of being by saying in being there is non-being. It means in subjectivity there is objectivity; they are brought together in unity.

Despite the positive aspect of Heidegger, he was also presumptuous. This is because he condemned the ideas of other philosophers. Philosophy is the history of ideas that grows through revolts and counter revolts 
among succeeding and preceding thinkers. To refuse to acknowledge the efforts of his predecessors would render baseless and orientationless his own philosophical system.

For Hegel, he believes that human reasoning can penetrate all realities, here Hegel should realize that there is limit to reason. Reasoning stops where faith begins. One does not discover God through reason but through faith.

\section{Conclusion}

We have come to the end of "Heidegger and Hegel on being". We give credit to both of them by discussing being which was abandoned. Heidegger believes that Being is a mystery. Whereas Hegel accepted that in being there is non-being and also that the Absolute spirit is not God but the principle that governs the universe. Hegel and Heidegger never mentioned that being is God. For me, there is a better understanding of being today. There is a "Pure Being" which is the originative cause of all things and all creatures terminate in him. This being is God and unless we return to God human beings can never have peace. Heidegger and Hegel are silent about God. Even though, Heidegger says that human beings have lost regard for themselves and now pursuing material things. Hegel said there is subjectivity in objectivity. The society well being cannot be achieved by mere economic and social arrangements but through individual and collective decision to return the proper understanding of Being, for me is God.

\section{References}

[1]. Rex Warner, The Greek Philosophers (new York: A Mento Books, 1958) p. 221

[2]. St. Thomas Aquinas, Summa Theologica (New York: The Modern Library, 1948) p. 783.

[3]. Immanuel Kant, Critique of Pure Reason (New York: Anchor Books, 1966) p. 627.

[4]. Jean-Paul Sartre, Being and Nothingness (New York: Methuen and Co Ltd., 1956) p. xxv. Also Omoregbe, History of Contemporary Philosophy p. 88.

[5]. Gabriel Marcel, Metaphysical Journal (Chicago: Henry Regnery Publication, 1952) p. 317.

[6]. Al. Fred, Metaphysics (New York: Anchor Books, 1972) p. 36.

[7]. Martin Heidegger, An Introduction to Metaphysics (New York: Anchor Books Doubleday \&Company Inc., 1961 ) p. 45.

[8]. Martin F. Asiegbu, "Why is there Something Rather than Nothing” in the Philosopher Magazine Published by the Nigerian Association of Philosophy Students, 1983, vol. 1. No. 1, p. 3.

[9]. Martin Heidegger, "Letter on Humanism” Translated by Edgar Lohner (New York: Harper \& Row Paperback Edition, 1971) p. 203.

[10]. Martin Heidegger, Discourse on Thinking (New York: Harper \& Row Publishers, 1966) p. 55.

[11]. C. S. Nwodo, "The Role of Art in Heidegger's Philosophy” in Philosophy Tochag, Vol. 1. No. 1. 1977 , p. 299.

[12]. Martin Heidegger, Identity and Difference (New York: Harper \& Row Publishers, 1969) p. 14.

[13]. Martin Heidegger, Identity and Difference p. 14.

[14]. Lasslo Versenyi, Heidegger, Being and Truth (New Haven: Yale University Press, 1965) p. 143.

[15]. G. W. F. Hegel, Philosophy of History (New York: Dover Publications, 1956) p. 15. 